\title{
PROBLEMS OF HAPPINESS IN THE ETHICAL THEORY OF TOMA AQUINSKY
}

In Happiness And Contemporary Society : Conference Proceedings Volume (Lviv, March, 20-21, 2021). Lviv: SPOLOM, 2021. P. 211-215. https://doi.org/10.31108/7.2021.48

ISBN 978-966-919-697-2

ОГІРКО Олег

\section{ПРОБЛЕМИ ЩАСТЯ В ЕТИЧНІЙ ТЕОРІЇ ТОМИ АКВІНСЬКОГО}

// Щастя та сучасне суспільство : збірник матеріалів міжнародної наукової конференції (Львів, 20-21 березня 2021 р.). - Львів : СПОЛОМ, 2021. С. 211-215. https://doi.org/10.31108/7.2021.48

ISBN 978-966-919-697-2 
https://doi.org/10.31108/7.2021.48

\section{OHIRKO Oleh}

Doctor of Philosophy, Associate Professor

Stepan Gzhytskyi National University of Veterinary Medicine and Biotechnologies

(Lviv, Ukraine)

\section{PROBLEMS OF HAPPINESS IN THE ETHICAL THEORY OF TOMA AQUINSKY}

The problems of happiness in the theological and philosophical heritage of the outstanding medieval scientist St. Thomas Aquinas are considered. The main source and basis of happiness according to Thomism is the Lord God himself. Happiness cannot be fully comprehended in the material world, in wealth, in intellectual knowledge. Human happiness does not consist in honors, in human glory, strength, goodness and pleasures of the body. Happiness is realized in human virtue. Happiness does not consist in human feelings, but it is revealed in thoughts about God.

Man will experience perfect happiness in another supernatural world through contemplation of God, who is the highest good and truth.

The teachings of the Catholic Church on the understanding of happiness are analyzed. Attention is drawn to the Message of Pope Francis on the occasion of World Youth Day in 2015. It is pointed out that God himself placed "in the heart of every man an unbridled desire for happiness and fullness". Ten key topics that guide a person to achieve true supernatural, eternal happiness are considered. Ways to live in happiness through a state of joy, love, friendship, humor, gratitude, the ability to forgive and ask for forgiveness are offered. In trying to achieve a happy state, it is important to rely on God in everything, as well as to realize that we are loved.

KEYWORDS: Toma Aquinsky, happiness, knowledge, will, love, goodness, joy.

$$
\begin{gathered}
\text { ОГІРКО Олег } \\
\text { доктор філософії, доцент } \\
\text { Львівський національний університет ветеринарної медицини та біотехнологій } \\
\text { імені Степана Гжицького (м. Львів, Украйна) }
\end{gathered}
$$

\section{ПРОБЛЕМИ ЩАСТЯ В ЕТИЧНІЙ ТЕОРІЇ ТОМИ АКВІНСЬКОГО}

Найвизначніший філософ і теолог Середньовіччя Тома Аквінський (12251274) вважав, що остаточна мета життя людини у досягненні щастя, а зміст щастя - у пізнанні Бога. Тома Аквінський наголошував, що Бог як “шлях, істина й життя" (Ів. 14, 6) ототожнюється із щастям: "Бог за своєю сутністю є щастям, яке не належить нічому іншому”. Ніхто за своєю сутністю не може бути щасливий, але може бути щасливий тією мірою, якою він наближається до Бога, тобто до Того, Хто $є$ самим щастям.

На відміну від Арістотеля, етика якого носила евдемоністичний характер, святий Тома Аквінський розглядав Арістотелівську етику в поєднанні 3 євангельським вченням і теологією. Він вважав, що кінцеву мету людського щастя 
можна осягнути не в створених матеріальних речах, багатстві, чи в приємностях тіла, а тільки в Господеві Богові, Який є найвищим і досконалим добром. Саме у Богові знаходиться досконале щастя, бо Він є початком і кінцем всіх створінь. Згідно вчення Томи Аквінського лише Церква допомагає людині осягнути правдиве щастя, бо держава допомагає в осягненні стану тимчасового добра. Арістотель вважав, що щастя можна осягнути у земному життя, а Тома Аквінський наголошував, що його можна осягнути тільки в наступному житті після смерті.

Тома Аквінський підкреслював, що щастя людини не полягає в знанні, але в любові до Бога. Згідно його вчення, дія волі людини осягнути правду і добро $є$ вищою від інтелекту, бо воля спричиняє рух інтелекту до його дій. Дія волі до остаточного кінця, який $\epsilon$ щастям, $\epsilon$ благороднішою, ніж дія інтелекту. Щастя $\epsilon$ властивим добром інтелектуальної природи людини. Щастя мусить належати до інтелектуальної природи. Щастя, або блаженство складається істотно і принципово 3 інтелектуальної дії ніж 3 дії волі. 3 другої сторони, неможливо, щоб щастя було чистою дією волі. Щастя складається в основному із зрозуміння, ніж 3 дії волі [1, с. 138-139].

Якби яка-небудь дія волі була щастям, тоді ця дія була б або бажанням любові, або насолоди. Сама радість не є остаточним кінцем в розумінні щастя, а дії волі не можуть бути по суті щастям. Дієвість людини $є$ істотно iï щастям, за допомогою якої вона осягає Бога.

Щастя людини не складається з почестей. Воно не ідентифікується з гонором людини, ані з почестями. Досягнення щастя звершується через доброчесність людини. Щастя людини повинно бути чимось добрим, яке б людина досягла своє власною волею [1, с. 144].

Людське щастя не може складатися із слави. Вона не може бути найвищим добром, бо грунтується головним чином на похвалах. Найвище добро повинно бути для людини тим, що $є$ найбільш тривалим в людських справах. Слава в розумінні репутації $є$ найменш тривалою справою [1, с. 146].

Людське щастя не ототожнюється з багатством. Воно не $\epsilon$ найвищим добром людини. Багатство не забезпечує добра в самому собі. Найвище добро не може міститися в посіданні речей, які приносять людині користь. Доброчесна дія $\epsilon$ гідна похвали настільки наскільки вона є близькою до щастя. Найвище людське добро не є суб'єктом долі [1, с. 147].

Щастя не полягає у світській силі, бо вона не може бути найвищим добром. Сила може вживатися, як для добра, так і до зла, бо раціональна сила $є$ спроможна до протилежних наслідків. Людська сила $є$ найбільш недосконалою, бо вона $є$ закорінена у волю та опінію людини, в якій існує найбільша непослідовність. Людське щастя не полягає на зовнішньому добрі [1, с. 148].

Щастя людини не проявляється в добрі тіла, бо людське добро не полягає в здоров'ї, силі, чи красі тіла. Ці властивості є спільними у посіданні як добрих, так і злих людей, вони не є сталими і не є суб'єктом волі. Щастя є властивим добром людини [1, с. 149].

Людське щастя не полягає у відчуттях, бо це добро спільне для людей i тварин. Відчуття $є$ вартісними з огляду на їх ужитковість. Вони відносяться до добра тіла [1, с. 150]. 
Остаточне щастя і блаженство людини полягає в роздумі про Господа Бога. Останній кінець щастя людини полягає у роздумі над вічною правдою, що є для неї власним наміром. Людське щастя полягає в обміркуванні мудрості та в розгляді божественних справ [1, с. 151].

Святий Тома Аквінський вважав, що зовнішні блага, такі як багатство, честь, слава, влада, а також тілесні блага, такі як здоров'я, краса, тілесна сила та задоволення не можуть бути змістом правдивого, досконалого щастя. Володіння цими благами не може послужити ні головним, ні засадничим елементом щастя [2, c. 86].

На думку Т. Аквінського, “Щастя $є$ станом, у якому людина в якийсь спосіб оволодіває всіма об'єктами своїх природних бажань. Не залишається більше нічого, що могла би прагнути й шукати щаслива людина". “Якщо людський розум... пізнає щодо Бога не більше того, що Він $є$, здобута ним досконалість ще не означає, що Першопричина стала досяжною, і в розумі залишається природне бажання шукати причину. Звідси, він ще не є досконало щасливим. Отже, щоб бути досконало щасливим, розум повинен досягти саму Сутність Першопричини" [2, с. 86]. Тома Аквінський стверджував, що у спогляданні та інтелектуальних чеснотах людина втішається зародком того правдивого щастя, яке полягає у знанні істини. Він стверджував: "Недосконале щастя, досяжне у цьому житті, людина здатна здобути власними природними силами, так само як чесноту, в дії якої й полягає це щастя. Недосконале щастя, яке можна здобути тут, полягає передусім i принципово в спогляданні, а вже потім в операціях практичного інтелекту, що керує людськими вчинками та пристрастями. Остаточне і досконале щастя, яке очікуємо в прийдешньому житті, полягає цілковито в спогляданні” [2, с. 87].

Святий Тома писав, що: "Наявність друзів не $\epsilon$ необхідністю для людського щастя, тому що людина має вже всю повноту своєї досконалості в Богові. Щасливій людині потрібні друзі... і не для того, щоб мати 3 них користь, і не для того щоб захоплюватись ними, а для того щоб творити добрі справи для цих друзів".

Католицька Церква найактивніше поширює вчення святого Томи Аквінського. У посланні з нагоди Всесвітнього дня молоді 2015 р. Папа римський Франциск зазначав, що "шукання щастя притаманне всім людям всіх часів, у кожному віці”, тому що сам Бог помістив “у серце кожної людини нестримне прагнення щастя і повноти”. Наші серця “неспокійні і постійно перебувають в пошуках добра, спроможного втамувати спрагу нескінченності”. Повчання Папи про щастя можна узагальнити, розглядаючи десять ключових тем [3].

1. Радість приходить тоді, коли ми починаємо бути уважними до інших

Щоб ступити на шлях до щастя, потрібно прямувати проти течії, тобто позбутися егоїзму і почати думати про інших. Як зазначали пустельники, сум з'являється тоді, коли ми думаємо про себе. Папа Франциск наголошує, що, коли життя побудоване виключно навколо власних інтересів і відсутній простір для інших, людина не може досвідчити “солодкої радості" любові. Потрібно долати спокусу замикатися в собі, ізолюватися, вважаючи себе самодостатніми, бо ми всі потребуємо взаємної підтримки. В Апостольському напоумленні "Evangelii gaudium" (Радість Євангелія), Папа пише: “Якщо мені вдасться допомогти принаймні одній людині жити краще, цього буде достатньо, щоб виправдати дар життя" [3]. 


\section{2. Проганяти меланхолію}

Наступник святого Петра часто цитує книгу Сираха: "Мій сину, якщо тільки маєш, добре дбай про себе, а й Господеві чини достойні приносини. Себе не позбавляй благосної днини, з доброго бажання не пропускай нічого" (Сир. 14, 11. 14). "Бог бажає щастя своїм дітям також і на цій землі, навіть якщо вони покликані до вічного звершення, бо Він сотворив усе, щоб всі могли цим насолоджуватися", - зазначає Папа у вже згаданому посланні 3 нагоди Всесвітнього дня молоді. Він наголошує, що Бог хоче, аби ми були позитивними і щодня вміли радіти маленькими речами та щоб не були в'язнями нескінчених тягарів і негативних думок. Справжня святість, за його словами, - це радість [3].

3. Радість приносять не влада, гроші, чи миттєві насолоди, а любов

“Якщо ми прагнемо успіху, насолоди, егоїстичного володіння, вчиняючи їх ідолами, то ми, можливо, переживатимемо моменти насолоди, примарне почуття задоволення, але вкінці ми стаємо незадоволеними рабами, нас постійно тягне шукати чогось більшого",- наголошував Вселенський Архиєрей, звертаючись 3 нагоди Всесвітнього дня молоді 2014 р. "Радість - це не миттєве насолода, а щось інше! - пояснював він під час зустрічі із семінаристами в 2013 р. - Справжня радість не походить від речей, від володіння. Вона народжується у взаєминах з іншими, коли усвідомлюємо, що нас приймають, розуміють і люблять та коли ми приймаємо, розуміємо і любимо; і це не задля миттєвого інтересу, а з огляду на те, що інший, чи інша є людиною. Радість народжується з безкорисливості зустрічі" [3].

\section{4. Почуття гумору}

Шлях радості, за словами Папи Франциска, передбачає також почуття гумору: вміти сміятися 3 себе, 3 інших, $з$ речей - це притаманно людині. Звертаючись 2018 р. до студентів церковних колегій, Святіший Отець закликав їх не сприймати себе занадто серйозно i, дивлячись у дзеркало, вміти посміятися 3 себе, щоб уникати самозакоханості. Про це говорив також Папа Венедикт XVI, цитуючи англійського письменника Гілберта Честерстона: “Знаєте, чому Ангели літають? Бо вони ставляться до себе з легкістю". "Якщо б ми не сприймали себе занадто серйозно, - додавав, Папа Ратцінгер, - ми, можливо, могли б літати трохи більше" [3].

\section{5. Вміти дякувати}

Радість - це також здатність бачити дари, які ми щодня отримуємо. Це захоплення красою життя і всім тим, що наповнює наші дні. Папа Франциск вказує на приклад св. Франциска з Ассізі, який вмів дякувати за кусок зачерствілого хліба. "Іноді, смуток пов'язаний з невдячністю, - читаємо в Апостольському напоумленні про святість "Gaudete et exsultate", - коли людина настільки закрита в собі, що нездатна розпізнати Божі дари” [3].

6. Вміти прощати і просити прощення

В серці, повному злості і жалю, немає місця для радості. Той, хто не прощає, шкодить, насамперед, самому собі. Ненависть породжує смуток. Вміння прощати походить з усвідомлення того, що Бог нас прощає. Вселенський Архиєрей цитує книгу пророка Софонії "Виспівуй, о дочко Сіону! Вигукуй радо, Ізраїлю! Господь усунув засуди проти тебе" (пор. Соф. 3, 14.15), додаючи, що “сумне обличчя" вказує на те, що людина не усвідомлює Божого прощення [3].

7. Радість праці і відпочинку 
Папа Франциск заохочує досвідчувати радість в праці з іншими й для інших, аби будувати кращий і більш братерський світ. Йдеться про те, щоби жити Блаженствами, які, за словами Святішого Отця, “не вимагають неймовірних дій”. Це стиль життя тих, хто відчуває потребу в Бозі. Це прості люди, що “як і всі інші, дихають повітрям, забрудненим існуючим у світі злом, але на своєму шляху ніколи не втрачають 3 поля зору слід Христа" [3].

8. Молитва і братерство

Шлях до радості не є легким, його утруднюють випробування і життєві невдачі, які спонукають до відчаю. Святіший Отець закликає відповідати на труднощі молитвою: "Можемо бути певні, - наголошував він під час загальної аудієнції у січні 2019 р., - що Бог відповість на нашу молитву, навіть, якщо вона, іноді суха. Можливо, нам потрібно буде молитися все життя, але Він відповість”. За словами Папи, молитва змінює дійсність: вона змінює або наше серце, або обставини. Молитися означає також усвідомлювати, що на своєму шляху ми не самотні [3].

9. Покладатися на Бога

В житті бувають моменти терпіння, коли почуваємося покинутими Богом і в ці хвилини, більше ніж будь коли, потрібно покладатися на Бога. І тоді, як пояснює Папа Римський в "Evangelii gaudium", ми ступаємо на ще одну сходинку радості, якою $є$ мир, той глибокий мир, що походить 3 повного уповання на Бога. Це надприродна радість, яку ніщо не може знищити. “Добра Новина, наголошує Папа, - це радість Отця, який не хоче, щоб ніхто з Його найменших був втрачений” [3].

10. Усвідомлювати, що ми люблені

Справжня радість, за словами Папи, народжується в зустрічі з Христом, Який полюбив нас і віддав за нас Своє життя. Радість - це знати, що Бог, Який $\epsilon$ Батьком, любить нас. Справжня радість не $є$ плодом власних зусиль, але даром Святого Духа, Який просить нас тільки відкрити серця для того, аби наповнити їх щастям. "Якщо ми дозволимо, щоб Господь допоміг нам вийти з власної оболонки і змінити наше життя, - читаємо в Апостольському напоумленні "Gaudete et exsultate", - тоді зможемо здійснити те, про що говорив св. Павло: "Радуйтеся завжди у Господі; знову кажу: Радуйтеся!". Радість - це слухати Бога, Який промовляє: “Ти важливий для мене, я люблю тебе і покладаю на тебе надіі”. У згаданому зверненні до семінаристів Папа зазначав, що радість приходить тоді, коли "відчуваємо, що Бог нас любить, що для Нього ми не цифри, а особи, коли чуємо, що Він нас кличе“ [3].

\section{ЛIТЕРАТУРА}

1. Олексюк В. Томізм. Християнська філософія св. Томи з Аквіну. - Чікаго, 1970. $-206 \mathrm{c}$.

2. Добко Т.Д. Св. Тома Аквінський про остаточну мету людського життя в “Сумі теології” (кн. I-II). Вісник Харківського національного університету імені В.Н. Каразіна. Серія “Теорія культури і філософія науки”, 1(940). Вип. 42. Харків, 2011. - $\quad$ C. 84-89. https://periodicals.karazin.ua/thcphs/article/view/1997

3. https://synod.ugcc.ua/data/shchastya-zgidno-z-vchennyam-papy-frantsyska-621/ 